
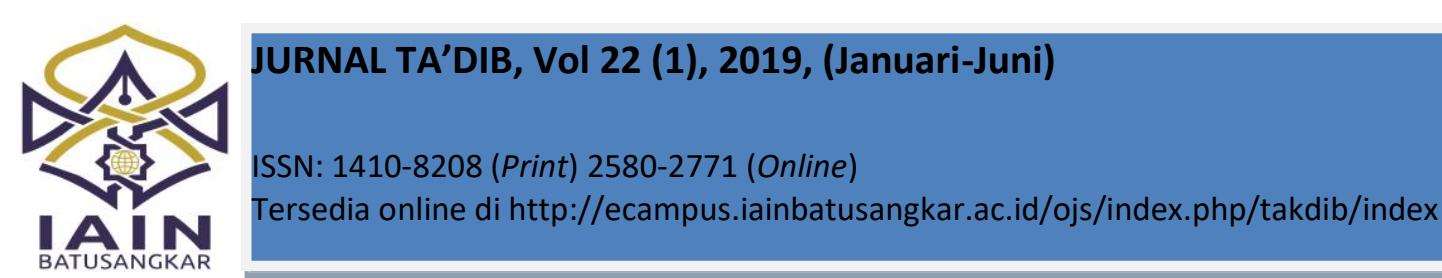

\title{
THE EFFECT OF ANTICIPATION GUIDE STRATEGY ON STUDENTS' READING COMPREHENSION
}

\author{
Mezia Kemala Sari *) \\ Universitas Muhammadiyah Sumatera \\ Barat, Indonesia \\ E-mail: meziakemalasari@umsb.ac.id
}

\section{Lisa Rana Sari* \\ MTs Muhammadiyah Kayu Tanam \\ Sumatera Barat, Indonesia \\ E-mail: lisarana.sari@yahoo.com}

\begin{abstract}
This research focuses on the influence of anticipation guide strategy on students' reading comprehension at the twelfth grade of MA KM Muhammadiyah Padang Panjang, 2017/2018 Academic Year. The research design was an experimental research conducted to the Science class as the participants of the research. The instrument of this research was a multiple-choice test distributed as the pre-test and post-test. As the result, the students' reading comprehension became significantly better after being taught by the anticipation guide strategy. It is found that the pre-test average score was 42.36, and after the treatment, the post-test average score was 75.7. The result shows that the anticipation guide strategy has significant influence on the student's reading comprehension.
\end{abstract}

*) Corresponding Author

Keywords: Reading Comprehension, Anticipating Guide Strategy

\section{INTRODUCTION}

$\mathrm{E}$ nglish has an important role in the world's communication as an international language. It is proved that many people in some countries tend to use English in their communication, either as a first or second language. English is also the key which opens the doors to scientific and technical knowledge, which is needed for the economic and political development of many countries, where English is mostly as a top requirement for seeking jobs. For the previous reasons, in Indonesia, English is taught in every level of education from junior high schools to colleges. English also becomes a compulsory subject which is tested in the national examination. In the national exam, English is always considered as one of the issues which is examined.

There are four skills in English: listening, speaking, reading, and writing. Although the students study integrated skills in English, reading tends to be faced by students in their course through written text because reading is needed for getting information from many sources like the magazines, newspapers, books and internets. Through reading, the student readers can get the authors' point or some information. Unfortunately, some students have difficulties in reading, especially English. It is caused by the language that is used. In Indonesia, English is as a foreign language, and the students tend to enjoy reading by using their national language (Bahasa Indonesia). For that cause, the students are too hard to understand what the point in English text is.

Reading is a complex, purposeful, interactive, comprehending, flexible activity that takes considerable time and resources to develop. Moreover, Reading as a rapid thing should maintain the flow of information at a sufficient rate to make connections and inferences vital to comprehension (Bojovic, 2014). Thus, the goal of reading is getting knowledge and information from what someone read and connect it by reader's brain, and if someone wants to master in reading, the reader should have a high comprehension of reading. Furthermore, for gaining the students' good understanding in 
reading a text, teachers have to provide the students with some strategies to improve the students' comprehension. The strategies can be used to make the learning atmosphere become enjoyable and increase their motivation. Besides, a text in reading is a potential challenge to be identified, and it must use the appropriate strategies to overcome the features in it (Ciuffetelli, 2018).

Choosing a strategy is determining and crucial because when talking about strategy, the things are related to the way that is selected with many considerations to gain the goal (Sari, 2015). One of the strategies that can be used in reading comprehension is Anticipation Guide Strategy.

Anticipation Guide Strategy firstly proposed by Herber (1978) as recently one of the strategies that is used by many researchers. It can also be used to observe the students' reading interest. Antoni (2017), in his research, attempted to find out the effect of anticipation guide strategy on students' comprehension of procedure text. He found that students who were taught by using Anticipation Guide Strategy had the better reading comprehension of procedure text than those who were trained by Small Group Discussion (Antoni, 2017).

Another previous research stated that after reading, students tend to integrate the new information they have received with their prior knowledge to form modified beliefs. The processes of making predictions before reading, monitoring comprehension during reading, and using fix-up strategies after reading represent comprehension processes that good readers possess which proves that Anticipation Guide Strategy can enhance the students' reading comprehension (Defrioka, 2018).

Based on the observation that has been done by the researchers in MA KM Muhammadiyah, most of the teachers of that school just used the general strategy in teaching reading. It influenced students' motivation and their achievement in reading. They looked bored and lazy to read the text that has been given by their teacher. It showed that the implementation of a conventional reading technique and the lack of reading strategies could not help the students to accomplish their task in reading class. Appropriate reading strategies are needed not only to overcome students' difficulties, but also to increase their reading comprehension. Therefore, anticipation guide strategy is required to help the students in comprehending reading texts, getting detailed information, and other reading tasks.

\section{METHOD}

The design of this research was experimental research which attempts to isolate and control every important condition which determines the investigated events and the observed effects when the situation are manipulated (Walliman, 2014). The type used was the equivalent experiment group design. This research was aimed to search whether there was or there was no effect of treatment which was done to the experimental subjects without random assignment. This design required one group that was the group that received a new (anticipation guide strategy) or experimental treatment. This group was given a pre-test and a post-test. The experimental group received something. In this case, $X=$ pre-test score before doing treatment, $T=$ treatment, and $Y=$ post-test score. The pre-test and the post-test scores were compared to determine the result whether there was influence of the treatment or not.

The setting of the research was Islamic Senior High School MA.KM Muhammadiyah. Its location is on Jalan Datuk Sinaro Panjang, Padang Panjang.

The population is the object in one area and have all of the particular requirements with the problem or object the research, or it means beyond the sample (Muhartoyo, 2014). The defined population has at least one characteristic that differentiates it from other groups. The population of this research was the students of the twelfth grade at MA.KM Muhammadiyah, which consists of 3 classes as presented below: 
Table 3.2

Population of the Research (Students of Twelfth Grade at MA KMM)

\begin{tabular}{|l|l|l|}
\hline NO & CLASS & TOTAL OF STUDENT \\
\hline 1 & ITT & 20 \\
\hline 2 & IPS & 14 \\
\hline 3 & IPA & 12 \\
\hline
\end{tabular}

Source: Administration of MA KM

The sample is part of the population, which is the process of selecting just a small group of cases from out of a large group (Walliman, 2014). In this research, sample that was used only one class for the experimental class using cluster sampling technique, because all of the classes were taught by the same teacher, and the teacher used the same strategy in teaching reading. Thus, it could be assumed that they have the same ability and capability. To be representative, some stages were followed:

a. Making the list of individuals.

b. Writing down each program of the class on a small piece of paper.

c. Deciding and choosing the class based on the criteria representing population.

\section{RESULT AND DISCUSSION}

Learning is actually fun and exciting, at least when the curriculum is well matched to students' interests and abilities, and the teacher emphasizes hands-on activities (Brophy, 2004). It means, when the class is fun, the student will enjoy the lesson like reading comprehension lesson.

Anticipation Guide Strategy that was used in this research could influence the students reading comprehension and it was proved, in this research, that for each indicator the Anticipation Guide Strategy increased in percentage before and after the treatment. The research result is in line with the study conducted by Roozkhoon \& Samani (2013) stating that the use of Anticipation Guide Strategy had positive effect on Iranian EFL learners' reading comprehension on culturally unfamiliar passages, and Malebese, Tlali, \& Mahlomaholo (2019) who researched four grade second language learners' reading comprehension after being taught socially inclucive teaching strategy. The teaching strategy significantly the lerners' reading comprehension.
In this research, the three components like main idea, textual reference, and word meaning are used as the indicator to see the influence of using this strategy into the students' reading comprehension

Based on the result of the research, anticipation guide strategy is effective to increase students reading comprehension. It can be seen by the conclusion through the diagram below

Figure 4.3

The comparis on percentage of each indicator in pre-test and post test

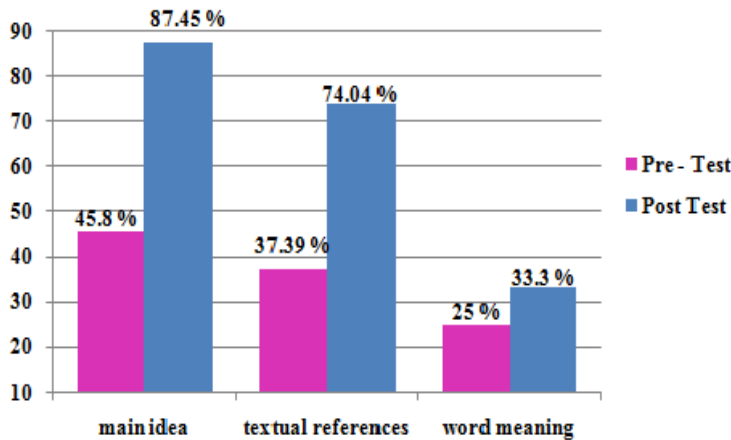

Based on the data which is presented in the figure above, there is distinguishing value in percentage between the result of pre-test and post-test. It indicates that there is an influence of anticipation guide strategy on students' reading comprehension. The percentage of indicators in post-test prove it tends to increase from the pre-test score.

The table above explains that the average score of pre-test of the main idea is 45 , and post-test score is 87 . Meanwhile, the average score of pretest about textual reference is 37 and post-test score is 74 . Then, the average score for word meaning pre-test is 25 , while the post-test average is 33. Most of students' score in science class increased. The average of pre-test score is 42.36, and post-test score is 75.7. In addition, the average result score from pretest to post-test is 33.34 .

Based on the previous data, it shows that the capability of students in reading comprehension is low before giving treatment (pre-test), after doing the treatment the students' ability in reading comprehension increased (post-test). Further explanation of students' achievement in reading comprehension, it can be seen in data analysis. 
There were some steps in data analysis. First is the description of the data that have been explained in the text above, second is comparison the data pre-test and post-test to find out the percentage of indicator that can be answered by the student.

After doing all the procedures of the research, it can be seen that anticipation has some advantage in its application to the students. An anticipation guide takes the process of reading content material from a purely passive state to active participation and discussion. Besides, this strategy is liked by students. Students appreciate the clear and direct format that anticipation guides afford, so, they are relatively easy to implement. After constructing and implementing a few anticipation guides, teachers appreciate their ease and simplicity.

Anticipation guide strategy can be useful in promoting decoding skills, enhancing word meaning, and strengthening comprehension. Based on the some advantages, Anticipation guide strategy also can be used in another subject like science, social, or another issue which related to the text. Furthermore, it is suggested to use this strategy for increasing student comprehension in teaching reading.

So, It can be clarified that anticipation guide strategy can influence students' reading comprehension. The students' achievement proves it tends to increase after using this strategy proved by the increasing students' mark in the test. It can be seen from the result of each indicator of reading comprehension; they are main idea, textual reference, and word meaning and the significant improving marks' average seen from each indicator. Herber (1978) stated that this strategy is suitable to help to activate students prior knowledge and as the guide in learning. So, anticipation guide strategy is one of strategy in teaching reading to increase students' reading comprehension, and it is quite similar to the previous researches conducted by another researcher.

\section{CONCLUSION}

The main concern in this research is the discussion of the influence of anticipation guide strategy on reading comprehension of twelfth-grade students in MA KM Muhammadiyah Padangpanjang in 2017/2018 academic year.

Anticipation Guide strategy can influence students' reading comprehension. The students' achievement tends to increase after using this strategy proved by the improving students' mark in test from the result of each indicators of reading comprehension; they are main idea, textual reference and word meaning and the significant improving marks' average clearly seen from each indicator.

Since this strategy is one of the problem-solving in teaching reading, the researcher suggests that the next researchers can develop this research with the more indepth and more intensive analysis with a different point of view. Hopely, the idea and the result of the research can help and motivate English teacher in teaching reading.

\section{REFERENCES}

Antoni, D. (2017). The Effect of "Anticipation Guide Strategy" and Students' Reading Interest on Students' Reading Comprehension at Grade XII of SMKN 1 Pariaman. English Language Teaching and Research, I(1), 65-76.

Bojovic, M. (2014). Reading Skills and Reading Comprehension in English for Specific Purposes, (March).

Brophy, J. (2004). Motivating Students to Learn.

Ciuffetelli, P. (2018). A guided reading research review. Nelson A Cengage Company.

Defrioka, A. (2018). Anticipation Guide : a Strategy of Teaching Reading Comprehension. Lingua Didaktika: Jurnal Bahasa Dan Pembelajaran Bahasa, $\quad 6(2), \quad 79$. https://doi.org/10.24036/ld.v6i2.7257 
Malebese, M. L., Tlali, M. F., \& Mahlomaholo, S. (2019). A Socially Inclusive Teaching Strategy for Four Grade English Second Language Learners in a South African School. South African Journal of Childhood Education.

Muhartoyo. (2014). Introduction to research methodologies, (45), 11-18.

Roozkhoon, M., \& Samani, E. R. (2013). The Effect of Using Anticipation Guide Strategy on Iranian EFL Learners' Comprehension of Culturally Unfamiliar Texts. Mediterrane an
Journal of Social Sciences, 4(6), 127140.

Sari, M. K. (2015). Peranan Pemilihan Strategi dan Stilistika dalam Iklan di Televisi. REKAM: Jurnal Fotografi, Televisi, Dan Animasi, 11(1), 19-30. https://doi.org/10.24821/rekam.v11i1.1 290

Walliman, N. (2014). Research Methods: The Basics. Research Methods: The Basics. London and New York: Routledge Taylor \& Francis Group. https://doi.org/10.4324/9780203836071 